\title{
Qualitative and quantitative characterization of municipal solid waste and the unexploited potential of green energy in Tunisia
}

Taieb Wafi ${ }^{*} \mathbb{D}$, Afef Ben Othman ${ }^{1,2}$ and Mongi Besbes ${ }^{1,3}$

\begin{abstract}
Municipal solid waste management (MSWM) is one of the major environmental issues in Tunisian cities. Rapid growth in urbanization and population rates and the changes in people's lifestyle have prompted a dramatic increase quantity and a significant shift in the composition of municipal solid waste. There is insufficient data concerning the quantities and the composition of waste streams along with the absence of a comprehensive complete overview and a wider perspective of MSWM potential that provides detailed information at region and city level. As a result, it is still impossible for the scientific community and the authorities to provide synergetic schemes to tie the problems of MSWM with how to integrate economically feasible and environmentally sustainable practices holistically. In the present study, an attempt has been made to provide a comprehensive overview of MSW, through a qualitative (compositional) and quantitative (parametric) characterization of the generated total waste generated in Tunisian cities. A 1-year research survey was conducted in seven regions in Tunisia (Great Tunis, Northeast, Northwest, Midwest, Mideast, Southwest, and Southeast) that cover the 24 provinces of the country. Collected samples revealed that the distribution of waste by region was defined by the region's demographic, economic, and industrial status. Approaches of possibly more efficient procedures that can be undertaken to improve MSW collection are discussed. At a final stage and based on the potential of biogas calculated in the seven regions, we suggest that the scientific community and the authorities should introduce applicable schemes to valorize MSW through generating biogas as a renewable energy.
\end{abstract}

Keywords: Waste valorization, Waste sorting, Biogas, Methane, Shortfall

\section{Background}

Solid waste management is a universal issue with various effects that depend on the amount of generated MSW and the strategies adopted by concerned authorities in its management. According to the 2018 World Bank Group estimates, the annual global generation of waste was 1.3 billion tons and was expected to reach approximately 2.2 billion tons by 2025 . In proportion to these approximations, there will be a momentous rise in per capita waste generation rates, from 1.2 to $1.42 \mathrm{~kg}$ per person per day in the next 15 years (Kaza et al. 2018).

\footnotetext{
*Correspondence: taieb.wafi@yahoo.fr

${ }^{1}$ Laboratory of Robotics, Informatics and Complex System, University of Tunis El Manar, Tunis, Tunisia

Full list of author information is available at the end of the article
}

However, these rates vary considerably by region, country, city, and even within cities because of many factors. The higher the income level, the population growth and urbanization rates are, the greater the amount of solid waste produced will be Trang et al. (2017). Therefore, it is estimated that the MSW generation will triple in higher-income countries and double in middle- and lower-income countries (Kaza et al. 2018; Paritosh et al. 2017). Earlier research showed that although still developing, low- and middle-income countries are encountering a consistent population and urbanization growth, economic prosperity and a rapid rise in community living standards that have significantly accelerated their municipal solid waste generation rates (Minghua et al. 2009). This shift has created a consistent change in people's lifestyles as evidenced by an emerging need to consume 
manufactured, non-biodegradable products. This alteration has represented a big challenge for traditional MSWM models in low- and middle-income countries (Eriksson et al. 2017).

Generally every municipal authority should adapt its management strategies to the evolving amounts and composition of the generated waste in the area under its jurisdiction. The challenges of MSWM come chiefly with the soaring levels of waste generation, the burden of responsibility that rests on municipalities to collect the budget to maintain MSWM strategies, the lack of a comprehensive overview of a diversity of factors that affect the different stages of waste management and connections necessary to enable the entire handling system functioning (Guerrero et al. 2013).

In Tunisia, although waste management has always been one of the strategic pillars of the policy of the government, and with the existence of sparse research on the issue (e.g., Bouallagui et al. 2005), the year 2011 associated with social, economic and political unrest has been marked by an alarming degraded municipal performance in terms of solid waste management in both urban and rural areas, which manifests in the proliferation of solid waste dumps and blackheads (Deutsche Gesellschaft für Internationale Zusammenarbeit (GIZ) 2014).

Along with the MWM issue and analogous to lowand middle-income developing countries, Tunisia has been facing energy deficit issues. Consequently, recent research (e.g., Mihai and Ingrao 2018; Miezah et al. 2015; Khandelwal et al. 2018; Panepinto and Zanetti 2018; Noya et al. 2018) has embarked on assessing schemes of MSW valorization that may enhance energy recovery, human health protection and the environment preservation. Scarlat et al. (2015), for instance, have investigated, at the African level, how waste could play a crucial role in providing citizens with energy extracted from waste incineration and from landfill gas (LFG). The results of the authors' study revealed that, in case of appropriate MSWM schemes, all waste generated in Africa has an energy potential that can grow from PJ in 2012 to 2199 PJ in 2025. These schemes should tie the problems of MSW management with how to integrate economically feasible and environmentally sustainable practices holistically. Having enough data about the complex physical composition of waste is mandatory to the design of the appropriate energy recovery scheme.

Generally, the scientific community MSW classifies MSW into organic degradable and inorganic waste (Ayodele et al. 2017; Majeed et al. 2018). Degradable waste which could be used as raw material for biological conversion processes like composting, biogas and bioethanol refinery process (Miezah et al. 2015). Part of previous research has assessed the benefits of solid waste management as soil fertilizer. Cherif et al. (2009) and Gwenzi et al. (2015) assessed the effectiveness of MSW application on agricultural soil in northern Africa arid climate and recommended using MSW compost at a rate of $40 \mathrm{Mg} /$ ha to fertilize wheat crops. Many researchers (e.g., Abbasi and Gajalakshmi 2015; Bhat et al. 2017; Sarkar and Chourasia 2017; Chaturvedi and Verma 2015) suggested adding different kinds of bacteria to improve the speed and quality of composting processes. Abbasi and Gajalakshmi (2015), for example, used termites to decompose substances which resist composting, vermin composting, or anaerobic digestion such as cotton waste, coconut shells, and torn jute bags. Similarly Chaturvedi and Verma (2015) argued that malachite green (MG), which is found to be toxic to aquatic organisms, animals including humans can be decomposed by the addition of a bacterium labeled Ochrobactrum pseudogrignonense, which was discovered in copper mine waste water.

Moreover, an abundant research body started investigating the possible generation of green energy. Research results showed that the application of mature municipal solid waste compost at a suitable rate of 40 tons/ha generally yielded a positive effect on the microbial biomass $\mathrm{BC}$ and $\mathrm{BN}$ in both cultivated and uncultivated soils (Singh and Ryan 2015). Other research results suggested the conversion of MW into biogas (Igliński et al. 2015; Hoo et al. 2017). Bouallagui et al. (2005) suggested that continuous two-phase systems are more highly efficient technologies for anaerobic digestion of fruit and vegetable waste (FVW) that can enhance the quantity of produced methane. However, their work was limited to fruit and vegetable waste and did not cover all type or organic waste.

Another valorization method of MSW oriented to electricity generation was through the application of many other methods such as landfill gas to energy (LFGTE) and waste to energy (WTE). After comparing these methods, for instance, Brunner and Rechberger (2015) found that WTE is more capable of producing an order of magnitude more electricity from the same mass of waste and is considered a better option under US renewable energy policies because it is more ecological.

In the same vein, Santoro et al. (2017) stated that in the past $10-15$ years, the scientific community has been focusing on the study of microbial fuel cell (MFC) technology and the possibility of transforming organic waste directly into electricity through microbially catalyzed anodic, and microbial/enzymatic/abiotic cathodic electrochemical reactions. MFCs are still at the center of several other recent publications (e.g., Yesuenyeagbe Fiagbe 2017; Chaturvedi and Verma 2016) that stressed the potential of the use of waste water in generating electricity. These new battery cells are being chemically and 
biologically improved to avoid the collapse of the output power in case of a significant current demand in the connected load. However, according to Chaturvedi and Verma (2016), the major drawback that impedes the MFC technology commercialization is its low power density.

In another study, Hirose et al. (2019) showed how electrochemically active bacteria (EAB) can be a promising technology for energy-generation electricity from biomass. After conducting a laboratory study of the Shewanella oneidensis MR1, the authors found that this bacterium was able to generate and conserve electrical power in different growth phases. They also suggested adjusting the structure of the biofilm to allow the electrons better circulate between the cells; a procedure that can prevent some electrode potential values from inhibiting EABs and blocking the electricity generation process.

In a different study, Chinnadurai et al. (2019) argued that because the food industry waste is rich in nutrient composition such as sugars, minerals and proteins and bioactive compounds, it should rather be considered as a raw material for other industries. They suggested the use of these "raw materials" that offer suitable conditions for the prolific growth of microorganisms that can result in generation of methane during solid-state fermentation (SSF) processes. In a similar study, Varadharajan and Subramaniyan (2014) isolated a new strain of Pseudomonas aeruginosa bacterium from oil contaminated site and suggested the application of agro-industrial wastes for biosurfactant production. Moreover, because the exploitation of wine by-products, using modern and inventive new extraction processes, is at the center of research in vineyards to limit negative effects on the environment, (Andorrà et al. 2019) have proposed ways to recycle grape pomace and emphasized the importance of enhancing the by-products of the wine industry.

Implementing efficient MSWM schemes can be capable of reducing major environmental impacts as pollution, global warming, and energy deficit, protecting human health and boosting social and economic sustainability (Tatàno et al. 2017). Therefore, providing comprehensive qualitative (compositional) and quantitative (parametric) characterization of the generated total waste generated in Tunisian cities is mandatory for this implementation.

For this reason, the main aim of this work is firstly to determine the quality and quantity of organic waste produced in different regions of Tunisia. Secondly, we aim to provide a comprehensive data on the unexploited potential of green organic waste resources throughout the whole country. This will help in planning and implementing relevant waste management schemes.

This paper is divided into four parts:

The first gives a comprehensive description of the methods and means used in the collection and classification of municipal waste in the different regions in Tunisia.

The second part comprehensive qualitative (compositional) and quantitative (parametric) characterization of the generated total waste generated in Tunisian cities. The third part provides an estimation of the potential of the biogas that can be generated from organic waste management performance parameters. An assessment of the shortfalls is also presented.

The paper ends with a conclusion providing recommendations on how to provide synergetic schemes to tie the problems of MSWM with how to integrate economically feasible and environmentally sustainable practices holistically.

\section{Materials and methods Study area}

The study was conducted in Tunisia which is located at latitude 33.8869171 and longitude 9.5374994, and it is part of Africa and the northern hemisphere. The country has 11.154372 million inhabitants and an average population density of 67.1 people per $\mathrm{km}^{2}$. The area of Tunisia is $162.155 \mathrm{~km}^{2}$, and it is divided into 24 provinces and 350 municipalities. These provinces are regrouped in seven regions (Great Tunis, Northeast, Northwest, Midwest, Mideast, Southwest, and Southeast) (Fig. 1).

\section{Materials and methods}

The data used in this work were collected in collaboration with the National Agency for Waste Management of Tunisia and some municipalities from the seven regions under study. In a preliminary stage, we focused on the measurement of the selected samples collected from twelve different municipalities in Tunis four provinces (Tunis, Ariana, Ben Arous, and Mannouba). The net quantity of collected waste from the four provinces was posited in $200 \mathrm{~kg}$ bins. The same conditions for each sample were checked and verified at each step.

We considered the steps below in sorting both organic and inorganic waste fractions: (1) waste coning and quartering, (2) manual waste sorting into material fractions and sub-fractions, and (3) the weighing procedures for each sorted material fraction or sub-fraction.

Based on weighing results, we determined the quantity of waste for each area.

We also carried the characterization analysis on samples taken at random during discharge. All samples showed high rates of moisture content, approximately $60 \%$, due to the presence of organic fraction. We pursued the same strategy during the sampling process in the remaining 20 provinces. 


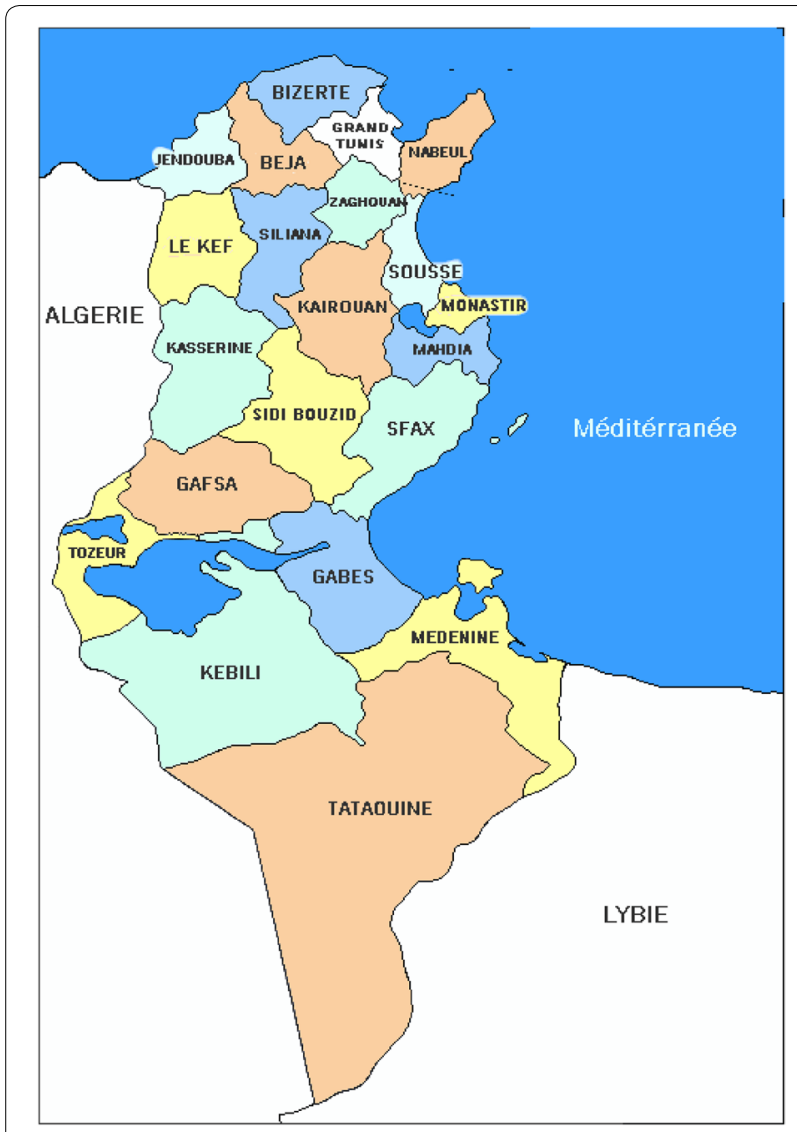

Fig. 1 Area of study

\section{Results}

Typology of recoverable organic waste in Tunisia Green waste from municipal and wholesale markets

This waste stream consists essentially of vegetable waste (vegetable toppings, spoiled or expired vegetables) which can be converted into biogas. $80 \%$ of this organic matterrich residue, whose composition requires small sorting operations, is produced in municipal and wholesale markets. Data concerning the total quantity of green waste (damaged fruits and vegetables) were gained through subtracting the sold and fresh unsold quantity of fruits and vegetables from the total quantity presented in the market. Figure 2 shows the estimated total quantity of waste, 18,000 tons/year, generated in municipal and wholesale markets in seven different districts.

\section{Waste from urban green spaces}

This category of residue comes from gardening waste, urban non-forest green areas (lawns, fencing and alignment trees, shrubs, flowers, etc.) and forestry (maintenance and pruning waste). Its generation is estimated at 3 tons/ha. The total area of green spaces is estimated at

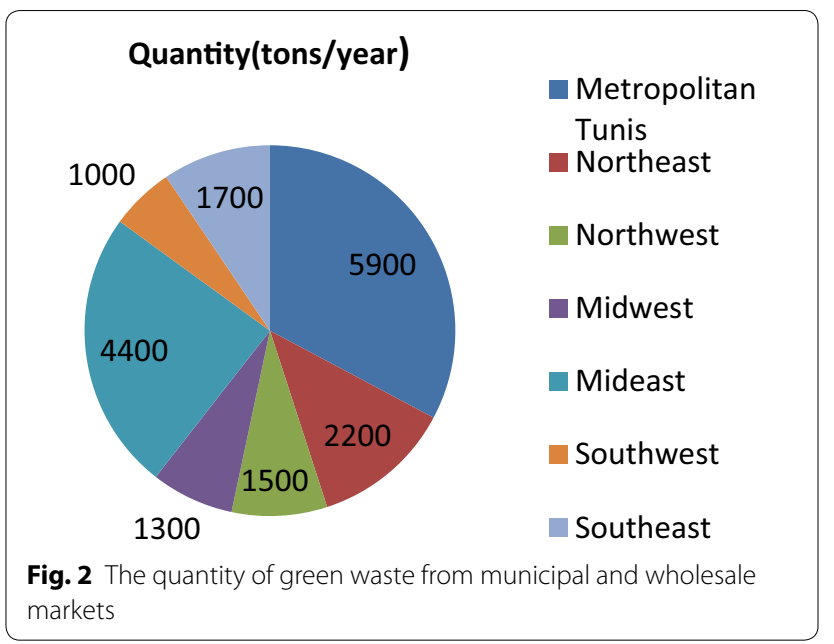

more than 10,000 ha, which generates a total amount of waste of around 31,500 tons/year divided by district as shown in Fig. 3.

\section{Waste from the food industry}

Agro-food industries are the second largest manufacturing industry with an added value of $20 \%$. Nearly $55 \%$ of agro-food production is accounted for by grain processing $(18 \%)$, which results in the production of $1,500,000$ tons of cereal straw per year, slaughter of animals (22\%) and olive oil production (15\%).

Agro-food production represents an important Tunisian industrial sector. Consequently, it has a significant environmental impact due to the large quantity of solid and liquid organic residues it generates throughout the processing chain, from the storage of agricultural products to pre-consumer processing. In spite of this, the

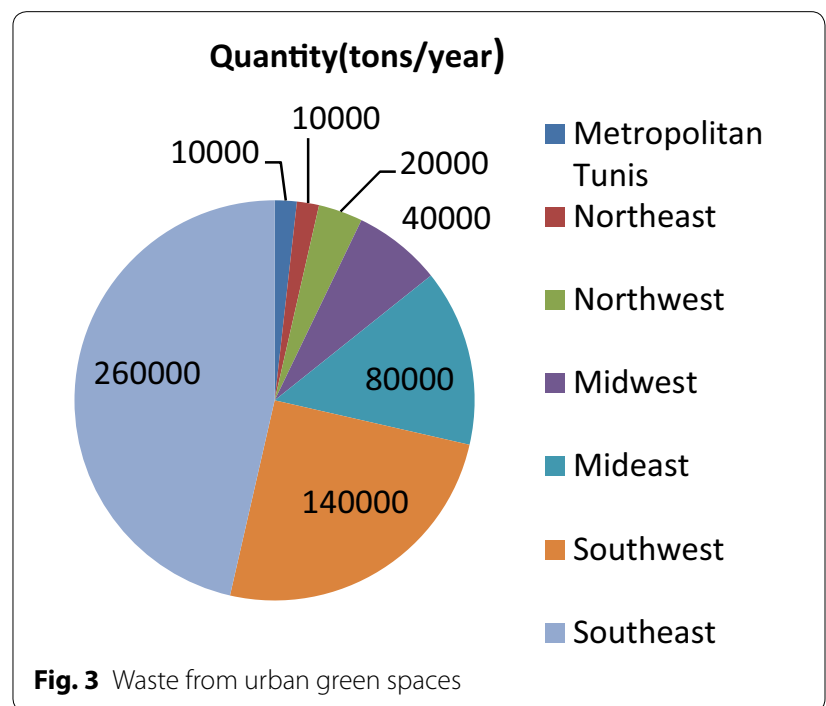


sector still lacks innovative strategies of waste recovery and valorization.

\section{Waste from fruit and vegetable canneries}

Changes in peoples' lifestyles resulted in the consumption of a great deal of canned food of which canned tomatoes represent about $90 \%$. The quantity of fruits, such as quinces, apricots, figs, pears, apples, peaches, oranges, and strawberries, oriented to the food cunning industry ranges from 8000 to 11,000 tons/year. The food cunning industry lies in three Tunisian areas; Nabeul with 50\%, the Metropolitan area of Tunis, with $21 \%$ and Beja with 13\% (Fig. 4). The waste deposit from fruit and vegetable canneries is currently estimated at 39,500 tons/year.

\section{Waste and by-products from oil mills}

Olive oil industry in the whole country generates a seasonal amount of solid olive mill waste (solid by-product) that ranges from 435,000 to 800,000 tons/year. The sludge quantity generated after the extraction process ranges from 120,000 to 168,000 tons/year depending on the extraction method: the traditional press method, the three-phase and the tow-phase decanter centrifuge.

\section{Olive mill wastewater}

Olive mill wastewater (OMW) is the liquid residue resulting from the three-phase extraction method of olive oil. This liquid is separated from oil through centrifugation or sedimentation after pressing.

Depending on the annual olive oil yield, $60 \%$ of which comes from the coastal area, about 1600 mills produce quantities of OMW varying from 600,000 to 1200,000 tons/year.

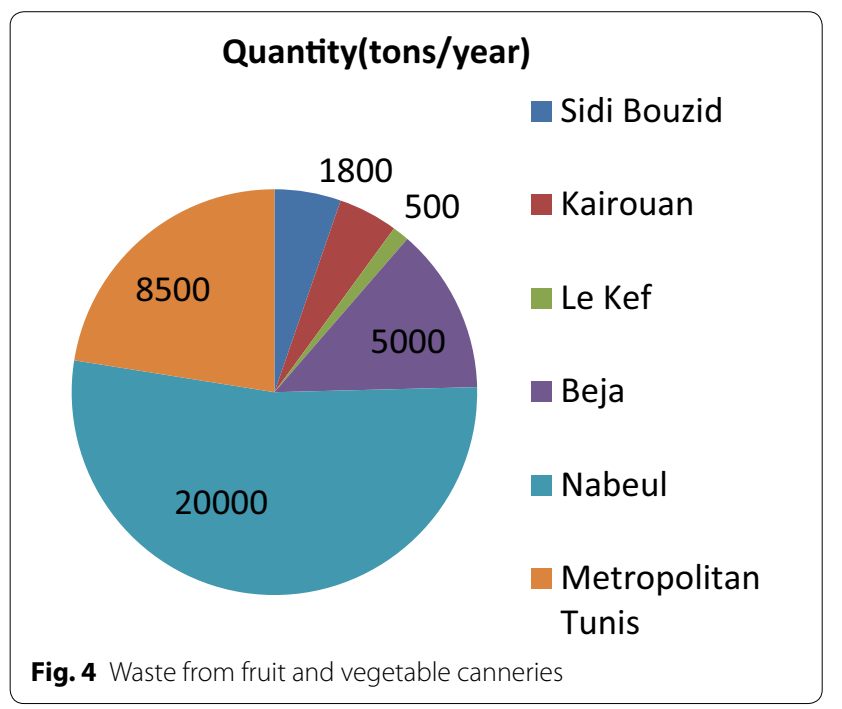

The estimated national volume of extracted OMW is 0.87 tons $/ 1$ ton of processed olive. In the future, it is predicted that the OMW quantities that will be generated from olive oil extraction processes are attributed not only to growth rates of olive corps, but also to the modernized extraction methods that release more wastewater. The distribution by region of annually generated quantities of OMW is provided in Fig. 5.

\section{Two-phase olive pomace (TPOP)}

The olive oil production industry produces, depending on the variety of olive crop, up to 650,000 tons/year of solid by-product that results from two main extraction processes. The first by-product is the olive cake resulting from three-phase centrifuge systems. However, TPOP is a thick sludge that contains pieces of stone and pulp of the olive fruit as well as vegetation water. The quantity of this produced sludge with high energy value ranges from 120,000 to 170,000 tons. The estimated national quantity of TPOP is 0.458 ton/ 1 ton of processed olive.

\section{Olive leaves}

The quantity of leaves collected at the oil mills and obtained after washing the olives is estimated at 5\% of the weight of the treated quantity of olive. For an annual quantity of treated quantity, leaf waste can reach 70,000 tons/year. These residues can be collected and used either to feed animals in composting.

The total quantity of organic waste from the olive branch is currently estimated at 2,090,000 tons/year.

\section{Waste from livestock slaughterhouses}

Thousands of tons of animal slaughter by-products waste is generated every year from slaughterhouses. These

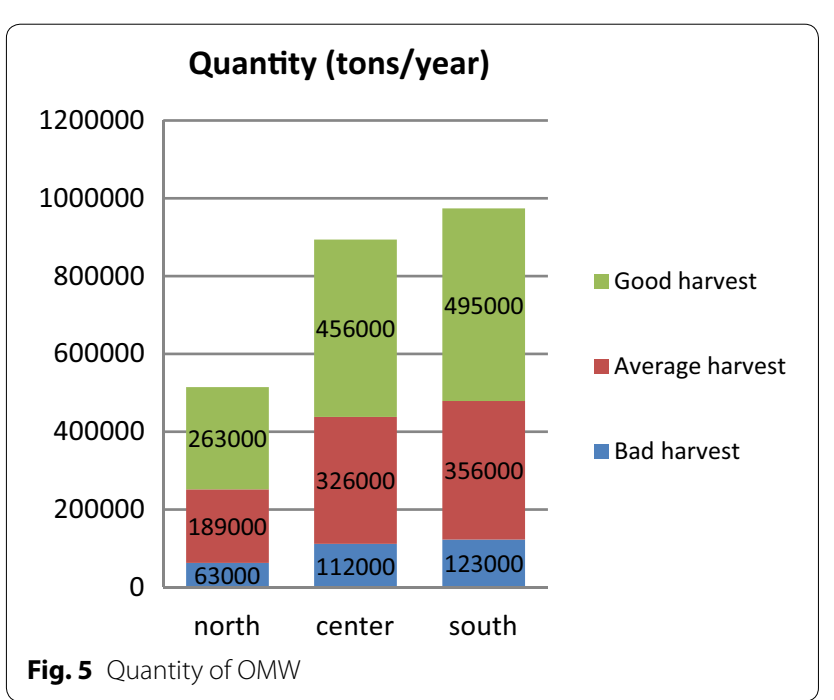


animal by-products have long been regarded as pollutants. However, recently research (e.g., Sindibu et al. 2018) abattoir waste can represent a sustainable waste management option because it has the potential of generating energy sources as biogas and bio-fertilizers.

Indeed, slaughterhouse waste is characterized by quick fermentability due to the presence of organic matter. Solid waste from slaughterhouses cannot be composted alone in the aerobic phase, because of its high moisture and poor structural stability. It is more suitable for anaerobic biomethanization treatment.

The existence of controlled livestock slaughterhouses allows for the estimation of the amounts of generated solid waste based on the weights of the slaughtered animals. This estimation reached 29,250 tons/year (Fig. 6).

\section{Waste from poultry slaughterhouses}

Today the chicken industry is vertically integrated starting from breeder flocks to the distribution stage. In addition to scientifically formulated feeds, advances in selective breeding, improved production technologies and better management practices have enabled vertically integrated poultry companies to grow broilers faster. This integration is resulting in greater efficiencies and higher product quality. Poultry industry where broilers are raised and slaughtered after approximately 6 weeks has been thriving in Tunisia. The industry also relies on strategic schemes through using stocks of frozen chickens to regulate the market.

Tunisia now possesses 18 industrial poultry slaughterhouses which are implemented as follows: 10 in the northeastern region (e.g., Nabeul, Ben Arous and Zaghouan), 5 in the center-eastern region (e.g., Sousse, Monastir, Sfax and Mahdia), 2 in the North West (Jendouba and Siliana), and 1 in the center-western (Sidi Bouzid).

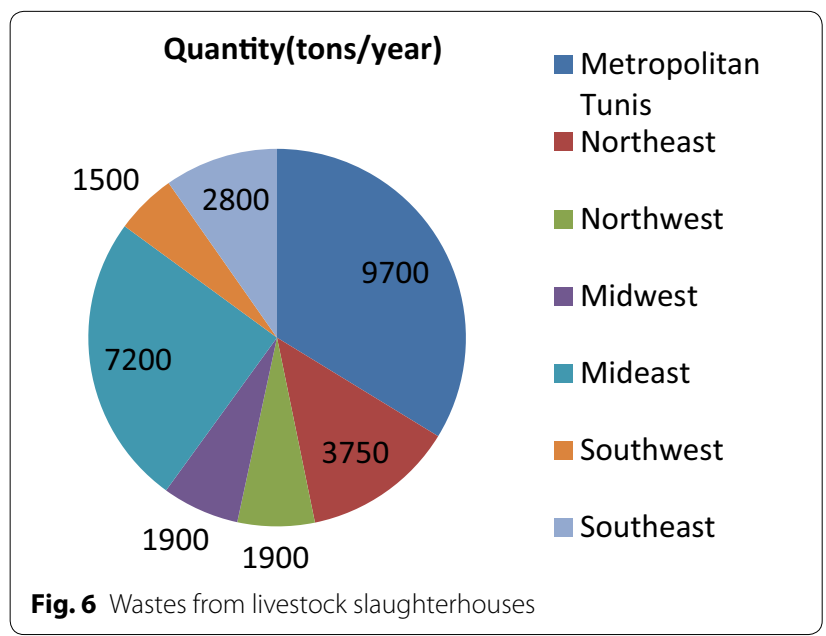

Taking account of the numbers of chickens and turkeys (approximately 72 million chickens and 4.05 million turkeys per year), the slaughter capacity is still enough in relation to the possible operation of 2 workstations/days.

The total quantity of waste generated from this activity is estimated at 47,580 tons/year divided by slaughterhouses in the different provinces as shown in Fig. 7.

\section{Organic waste from catering activities}

The waste generated from restoration activities in Tunisia consists mainly of:

- Vegetable oils and fats characterized by a high range of COD equal to $350 \mathrm{~g} / \mathrm{l}(100$ to $1000 \mathrm{~g} / \mathrm{l})$ and a calorific value of $9000 \mathrm{kcal} / \mathrm{kg}$.

The total quantity of this waste is estimated at about 68,600 tons/year, and it comes mainly from: hotels, university restaurants, private hospitals and clinics, and refectories.

Table 8 shows the quantity of recoverable organic waste from these four main sources (Figs. 8 and 9).

\section{Winemaking}

During the last decade, Tunisian viticulture has evolved both quantitatively and qualitatively. Based on changing climatic conditions grape-growing regions in Tunisia produce quantities ranging from 35,000 to 57,500 tons/ year. The eastern part of the country encompasses 40 industrial grape processing plants and produce significant quantities of grape stalk.

Industrial grape processing can result in many products such as juice and wine. Grape pomace or marc is a residue of grape processing in wine and juice which

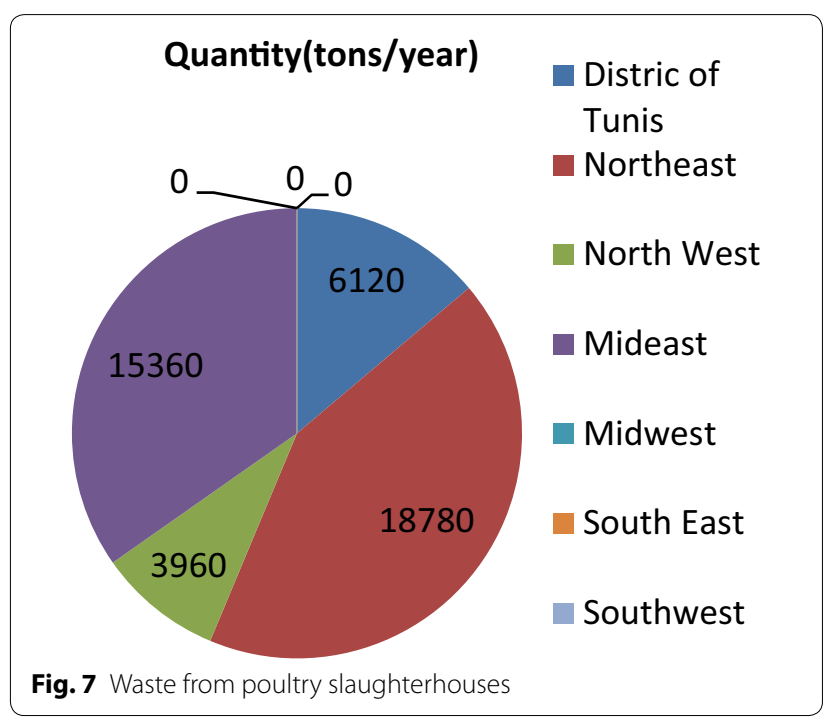



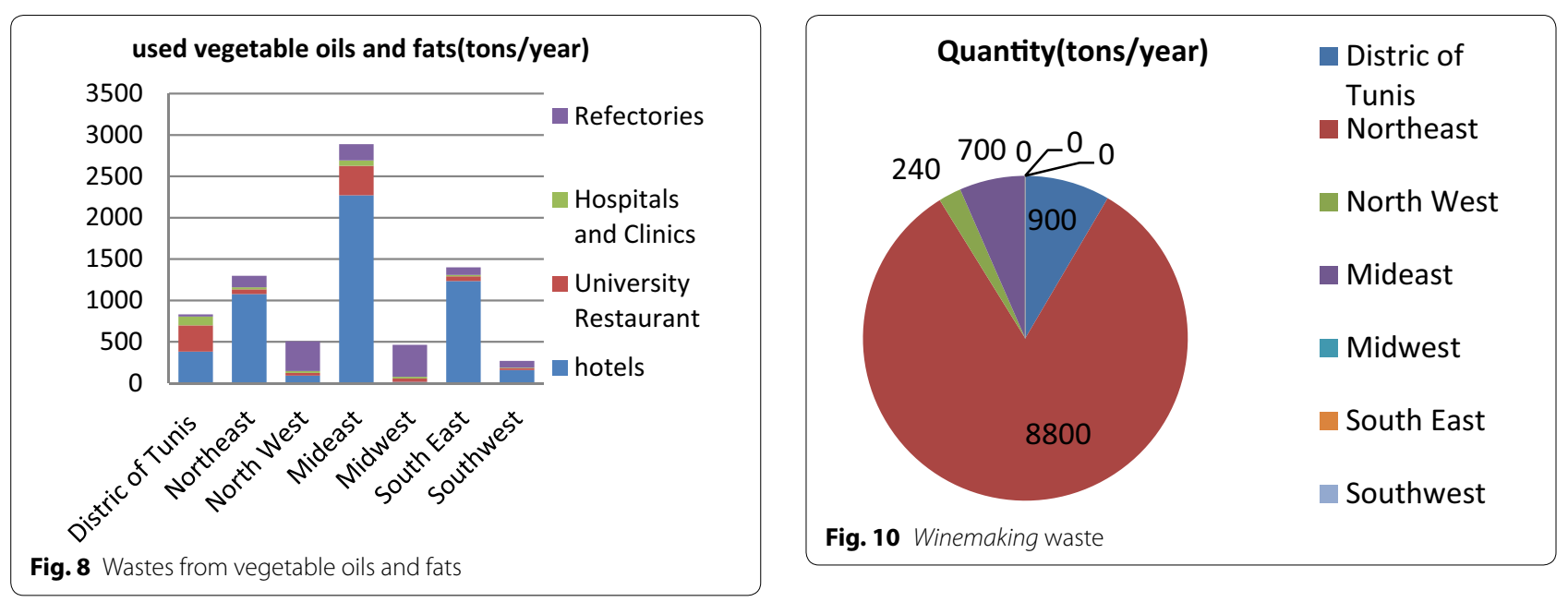

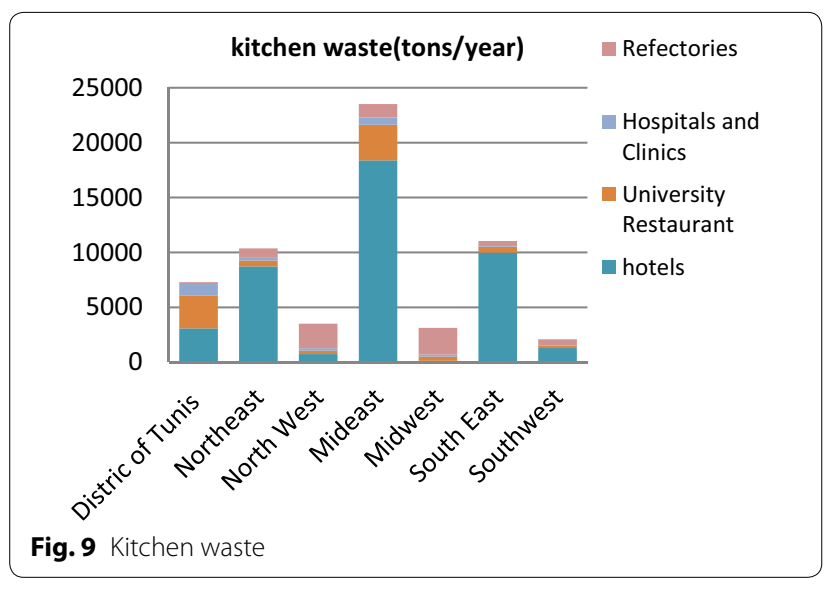

represents a challenging waste disposal problem for the winery and grape juice industry. However, recent research has suggested that this waste can be valorized to produce energy or to be used as an organic fertilizer.

At present, the processing of wine production yields almost 10,557 tons/year of grape marc, of which only $10 \%$ is intended for feeding the livestock, while the rest is either dumped used in heating in rural areas. A small part is currently used to make compost (Fig. 10).

\section{Manure and the droppings from the livestock sector}

Droppings from the livestock sector Poultry farming has become an integrated industry in Tunisia during the last decades. The poultry population in Tunisia is currently estimated at more than 70 million, of which $80 \%$ lies in Sfax (42\%), the second largest population is raised in Tunis (20\%) and 15\% in the Cape Bon, particularly in the city of Nabeul.

There are two types of droppings produced:

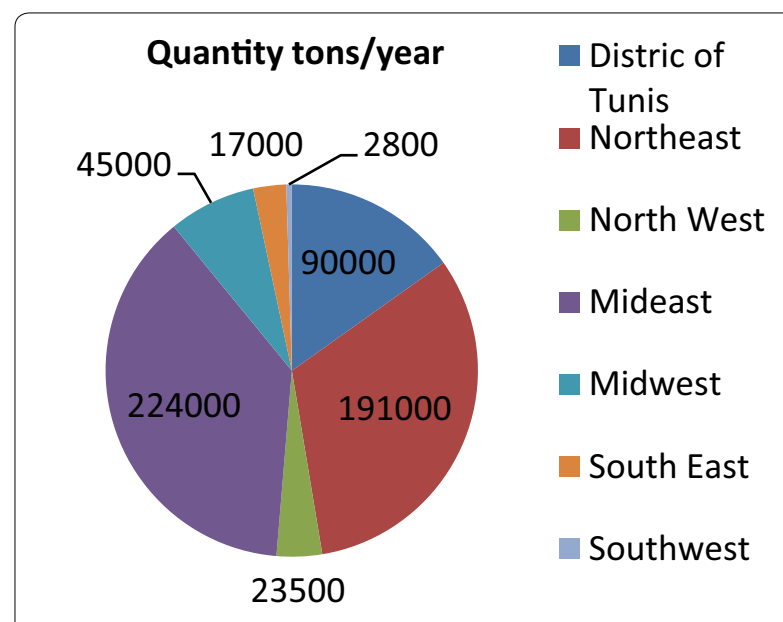

Fig. 11 Dropping waste

- Liquid droppings, which are found in flocks of laying hens.

- Solid droppings, which are found in broiler farms, breeding chickens and breeding stock, and in breeding turkey farms.

Collected samples revealed that there are 400,000 tons/ year in the form of slurry liquid which is easily recoverable by biomethanization, and 206,000 tons/year of dried droppings which are easily compostable (Fig. 11).

\section{Manure}

Manure, a by-product of livestock production, is a valuable fertilizer that provides necessary minerals for plants to grow. It plays a major role in agriculture, because due to the humid matter it allows to restore soil fertility. Economically, most often manure is underestimated. Under the best storage conditions, the lost quantity is $30 \%$, but without great care, as is often the case, it can reach $60 \%$. 
Indeed, it is relatively rare to find treated manure in good conditions. Manure is also commonly commercialized as a soil amendment but is a less fermented manner. In the some crops, it is sometimes a source of germs and weeds. The samples show that the total manure production of all species is currently estimated at 2,246,837 tons/year (Fig. 12).

\section{Waste from the wood industry (sawdust)}

Forest wastes This category of waste consists of dead wood and brushwood, pruning and forestry products. The deposit is very important, the bulk of which is currently burnt. A small part of the forest waste and by-products (Acacia pine bark, leaves and twigs) that are perfectly suitable for composting is currently used for the composting of modern forestry nurseries and the production of seedlings for reforestation (Fig. 13).

\section{Waste from the timber industry}

This category of waste comes from large sawmills and wood pulp mills, which represent the largest share of the sector upstream of a whole chain of other industries, and craftsmen of wood and furniture distributed throughout the country. The total quantity is estimated at 64,500 tons/year as shown in Fig. 14.

Agricultural waste Previous studies have shown that we can receive a general average of 2 tons of compost from waste coming from fruity trees, including olives and palm trees per hectare of dry crops and 3 tons/ha/year from irrigated crops. This makes the estimated quantity reaches 4,426,760 tons/year in the whole country.

In almost all cases, the leaves are used feeding livestock and branches are partly used as firewood for domestic heating. Other types of leaves (palm tree leaves) are used

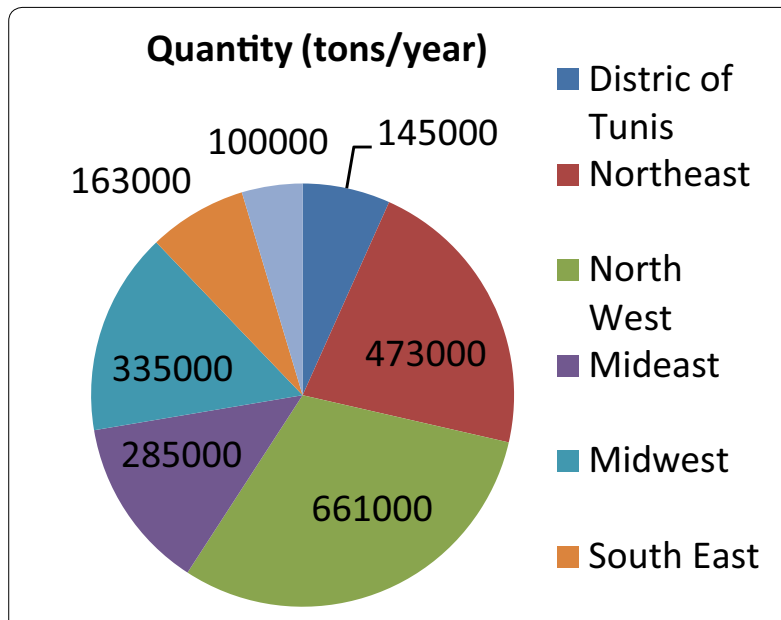

Fig. 12 Waste of manure

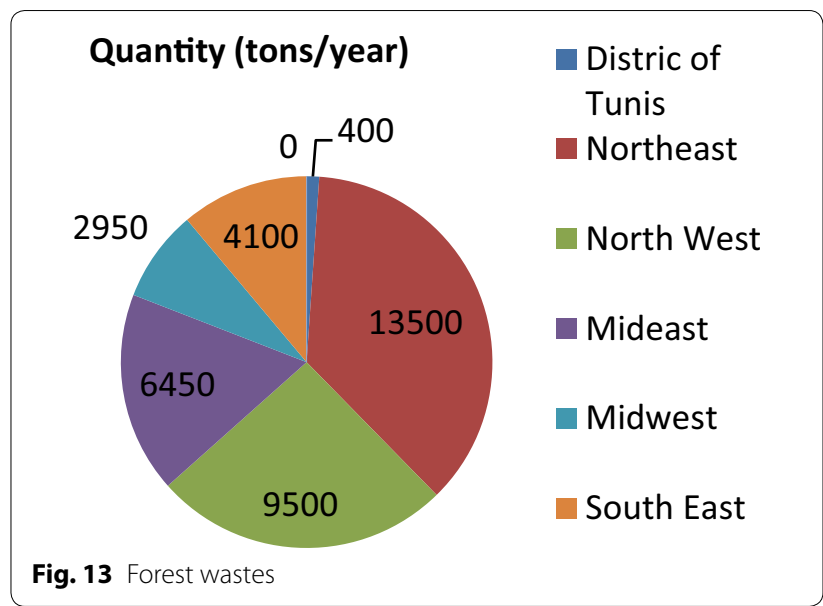

in craftsmanship (i.e., making hedges, wind erosion, and handicraft products such as hats, baskets, fans...).

Unfortunately, this deposit is not collectable in its totality. According to the forest inventory, about $50 \%$ of this quantity is used for wood fires, bringing the exploitable deposit to reach 2,245,380 tons/year. These quantities are distributed as shown in Fig. 15.

\section{The sludge treatment plants of wastewater}

Each year, nearly 260 million $\mathrm{m}^{3}$ of wastewater is produced in Tunisia. Only 225 million $\mathrm{m}^{3}$ of this volume is treated in 100 wastewater treatment plants (WWTPs) throughout the country. The total quantity of sludge produced was estimated at 175,000 tons/year in 2007 . This amount is predicted to go up to nearly 300,000 tons/ year by 2020 , about $40 \%$ of which will be produced in the metropolis area of Tunis. After the launch of the new El Attar station, 68\% this sludge is mechanically dehydrated and $32 \%$ is naturally dried. The good quality of a large part of this sludge, as well as their richness with

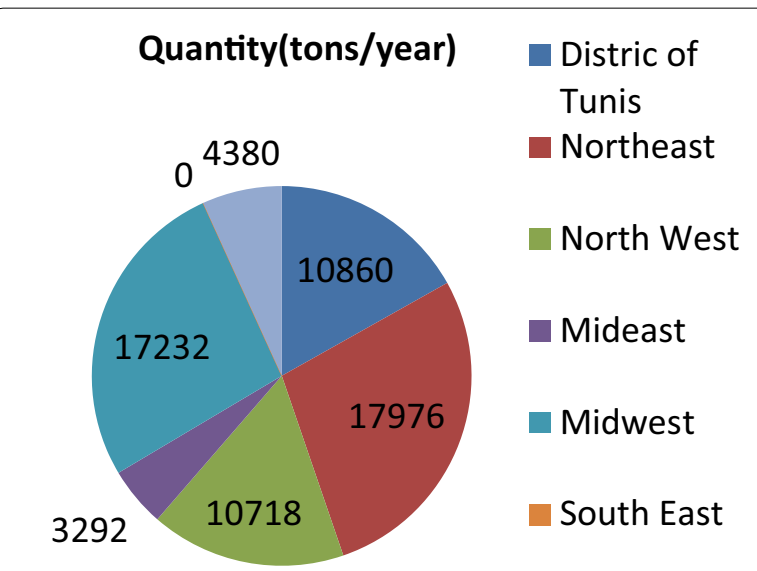

Fig. 14 Waste from the timber industry 


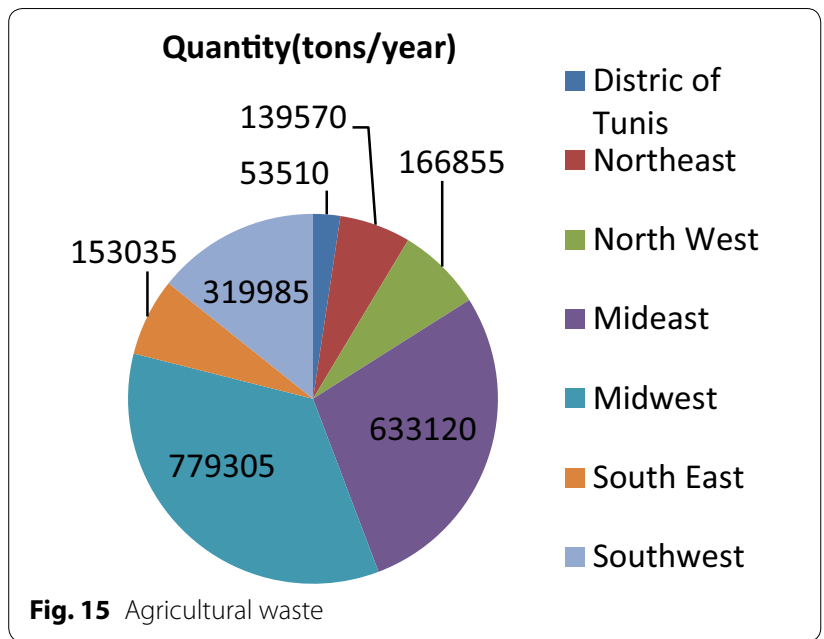

fertilizing elements a calorific value, offers a potential possibility for their direct reuse in the agriculture (Promulgation of Decree No 13 of 3 January 2007 on the use of sludge in agriculture); they can be used in co-composting or anaerobic digestion as part of an energy resource (Fig. 16).

\section{Synthesis and evaluation of the potential of organic waste in Tunisia}

Among the categories studied, in Table 1 we provide specified waste inputs, depending on their source, and which are best suited to material or energy recovery or both.

The combination of the various deposits according to the territorial proximity allows envisaging a better qualitative and quantitative valorization of the waste into energy.

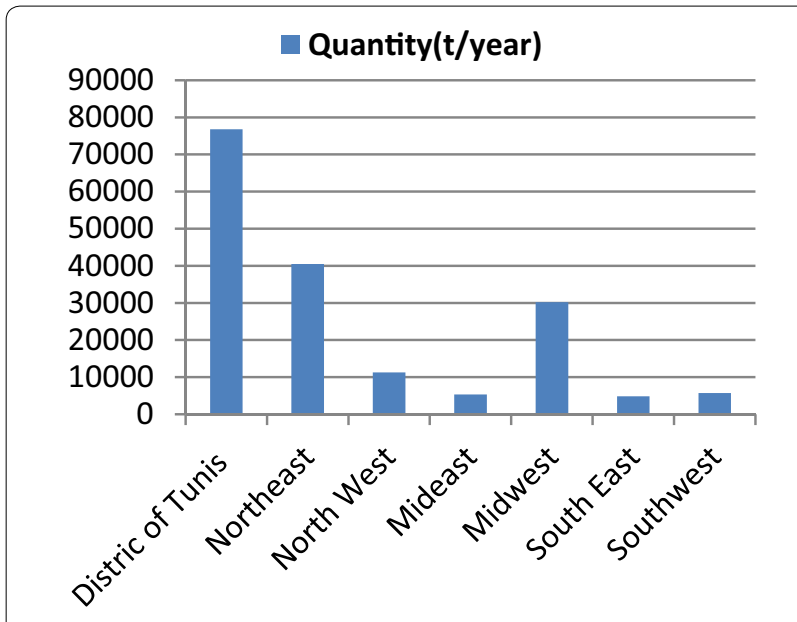

Fig. 16 Sludge wastewater treatment plants
Table 1 Classification of waste

\begin{tabular}{lll}
\hline Origin of the waste & $\begin{array}{l}\text { Material } \\
\text { recovery } \\
\text { (composting) }\end{array}$ & $\begin{array}{l}\text { Energy } \\
\text { recovery } \\
\text { (bio gas) }\end{array}$ \\
\hline Municipal and wholesale markets & $\times$ & $\times$ \\
Urban green spaces & $\times$ & $\times$ \\
Fruit and vegetable canneries & $\times$ & $\times$ \\
The margins & $\times$ & \\
Forest waste & $\times$ & $\times$ \\
Waste from the timber industry & $\times$ & $\times$ \\
Vinification & & $\times$ \\
Livestock slaughterhouses & & $\times$ \\
Poultry slaughterhouses & & $\times$ \\
Catering activities & $\times$ & $\times$ \\
Manure & $\times$ & $\times$ \\
Solid and liquid droppings & $\times$ & \\
Agricultural waste & & \\
Wastewater treatment plants (sludge) & & \\
\hline
\end{tabular}

The compositional and quantitative characteristics of waste, as well as their geographical distribution, represent an important element in evaluating the mobilizable potential for a valorization. A more precise approach to the inventory would be to examine the other local organic waste production sites (whatever they are).Then, depending on the distance between the main production site and the other sites, we suggest that it would be necessary that processing takes place in the same station.

Moreover, we have to consider that all identified waste types cannot be recovered using the same techniques; methanisation, for instance, cannot be applied to woody substrates, and composting is poorly suited to highly liquid substrates.

The analysis encompasses three main methods.

- Substrates which can be composted but not methanated (Fig. 17c),

- methanisable substrates (Fig. 17b),

- methanisable and composted substrates (Fig. 17a).

A first approach consists in making organic waste production and waste treatment happen in the same sites (material and/or energy recovery).

In this case, the following factors should be considered:

- The implemented site should work complimentarily with other organic waste generators in the vicinity,

- markets should be proximate to material recovery areas, 


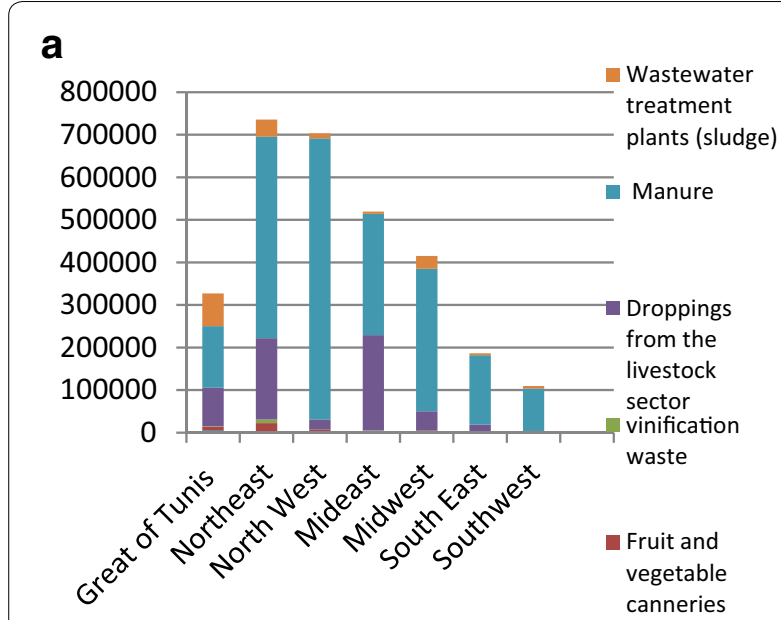

b

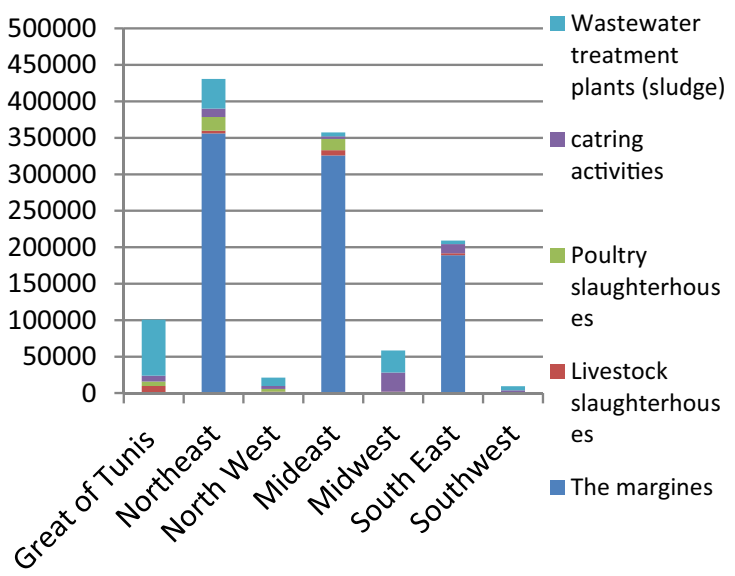

\section{C}

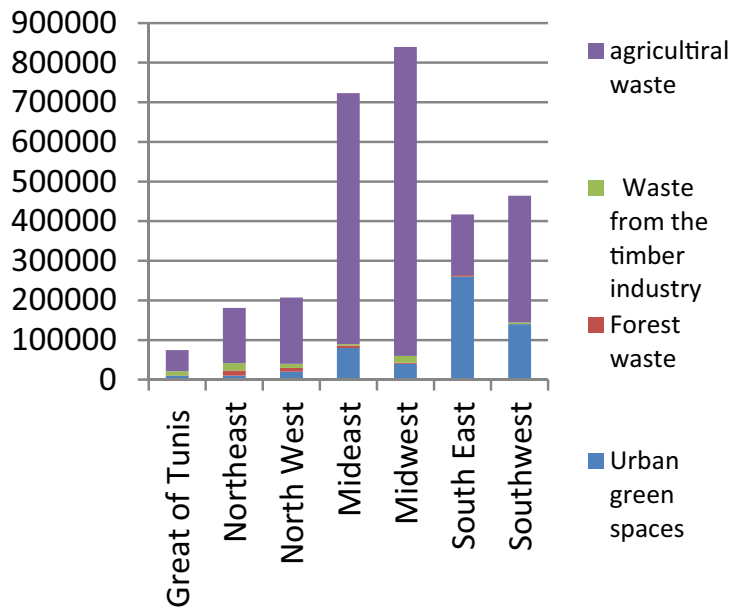

Fig. 17 a Quantities of methanisable and composted substrates (T/year). b Quantities of methanisable substrates (tons/year). c Quantities of composted substrates (T/year)
- depending on these two parameters, transport and neighborhood constraints should be considered when dealing with different locations.

A more detailed approach would be to examine the distance between the local organic waste production sites and the location of the main production sites.

Moreover, we suggest that the proximity of main and peripheral sites would allow MSW treatment in the same station.

The same analysis can be done by examining the distribution venues or marketing sites of the produced biomass (compost or methanisation effluent). At the commercialization phase, priority should be given to supplying compost users such as agricultural incubators, organic farms, irrigated crops, and private and public garden design. Consequently, a commercialization plan should be developed and outcomes can be achieved through identifying the potential areas. In these areas, the largest and most profitable projects can be vindicated as prior ones given the availability of raw materials that can satisfy local demand. Thus, an efficient scheme should not only be limited to collecting and transporting generated waste, but it should also include and additional operation where waste is mixed with organic fertilizers. Furthermore, there should be an alignment between demand and supply of compost at a regional level to avoid unfairly low prices at the marketing stage. Moreover, a procedure like this can allow the determination of the project's size according to farmer's needs. When supply exceeds demand, it would be wise that farmers manage their small projects that can meet their soil amendment needs on ad hoc needs on an ad hoc basis. Otherwise, it would be more interesting that the Tunisian authorities consider economies of scale and favor facilities of high or medium capacity.

\section{The potential of biogas in Tunisia}

A biomethanation process depends primarily upon seeding, temperature, $\mathrm{pH}$, carbon-nitrogen $(\mathrm{C} / \mathrm{N})$ ratio, volatile fatty acids (VFAs), organic loading rate (OLR), alkalinity, total volatile solids (VS), and hydraulic retention time (HRT) and nutrients concentration (Paritosh et al. 2017). There was also a significant variation. In this part of work, to identify the potential of biogas from different organic waste, we use the different results in the bibliography Table 2.

To calculate the energy input of the cumulative waste, the lower calorific value equal to $60 \%$ was considered 
Table 2 Potential of biogas from deferent substrate

\begin{tabular}{|c|c|c|}
\hline Substrate & $\begin{array}{l}\text { Average of biogas production } \\
\text { potential } \\
\mathrm{m}^{3} / \text { tons }\end{array}$ & References \\
\hline Vegetable waste & 60 & Oguntoke et al. (2019) \\
\hline Fruit and vegetable canneries & 60 & Recebli et al. (2015) \\
\hline Dry leaves & 118 & Einarsson and Persson (2017) \\
\hline Olive mill wastewater & 35 & Al-Addous et al. (2019) \\
\hline Winemaking & 160 & Saladié (2016), Al-Addous et al. (2017) \\
\hline Livestock slaughterhouses & 38 & Karaca and Öztürk (2017) \\
\hline Green leaves & 100 & Bowan and Tierobaar (2014) \\
\hline Poultry slaughterhouses & 180 & Makisha and Semenova (2018), Eriksson et al. (2017) \\
\hline Catering activities & 60 & Ogur and Mbatia (2013), Oyiwona et al. (2018) \\
\hline Manure & 60 & Kigozi et al. (2013), Tatàno et al. (2017) \\
\hline Solid and liquid droppings & 70 & Kumar et al. (2017) \\
\hline Agricultural waste & 60 & Akyürek (2018) \\
\hline Olive pomace & 82 & Chinnadurai et al. (2019) \\
\hline Yard waste & 100 & OjikutuAbimbola and Osokoya Olumide (2014), Deressa et al. (2015) \\
\hline Wastewater & 250 & Ciuta et al. (2016), Kumar et al. (2017) \\
\hline
\end{tabular}

- $1 \mathrm{~m}^{3}$ of biogas is equivalent to $6 \mathrm{kWh}$ (Sindibu et al. 2018)

- We assume that the price of $1 \mathrm{kWh}$ provided by the conventional source with the subsidy is equal to 0.18 USD (Bertheau and Cader 2019).

1 T.O.E (One Ton of Oil Equivalent) is equal to $11,620 \mathrm{kWh}$

\section{The potential of biogas in the Northwest of Tunisia}

Table 3 provides a synthesis of the total waste produced in the Northwest of Tunisia which is equal to $1,009,674$ tons/year.

The production of biogas combining the different waste in the same installation is estimated at $63.1710^{6} \mathrm{~m}^{3}$ equivalent to $379 \mathrm{Gwh}$.

This potential allows the gain of more than $53,870,720$, 7 USD. This analysis used to identify the energy of the region and to vindicate the urgent need to implement of profitable projects given the availability of raw materials.

Table 3 Potential of biogas he Northwest of Tunisia

\begin{tabular}{|c|c|c|c|c|c|}
\hline Waste & $\begin{array}{l}\text { Equivalent } \\
\text { in energy } \\
\text { GWh }\end{array}$ & $\begin{array}{l}\text { Production } \\
\text { tons/year }\end{array}$ & $\begin{array}{l}\text { Potential } \\
\text { of biogas } 10^{6} \mathrm{~m}^{3}\end{array}$ & Equivalent in TOE & Gain in USD/year \\
\hline Margin & 74.76 & 356,000 & 12.46 & 6433.73 & $13,456,800$ \\
\hline Livestock slaughterhouses & 0.86 & 3750 & 0.14 & 73.58 & 153,900 \\
\hline Poultry slaughterhouses & 20.28 & 18,780 & 3.38 & 1745.47 & $3,650,832$ \\
\hline Catering activities waste & 4.20 & 11,672 & 0.70 & 361.61 & $756,345.6$ \\
\hline Liquid dropping & 31.50 & 75,000 & 5.25 & 2710.84 & $5,670,000$ \\
\hline Sludge waste water & 60.71 & 40,472 & 10.12 & 5224.44 & $10,927,440$ \\
\hline $\begin{array}{l}\text { Green waste from markets municipal and } \\
\text { wholesale }\end{array}$ & 0.79 & 2200 & 0.13 & 68.16 & 142,560 \\
\hline Fruit and vegetable canneries waste & 7.20 & 20,000 & 1.20 & 619.62 & $1,296,000$ \\
\hline Winemaking waste & 8.45 & 8800 & 1.41 & 727.02 & $1,520,640$ \\
\hline Manure & 170.28 & 473,000 & 28.38 & $14,654.04$ & $30,650,400$ \\
\hline Total & 379.03 & $1,009,674$ & 63.17 & $32,618.53$ & $68,224,917.6$ \\
\hline
\end{tabular}


Table 4 Potential of biogas in the Northeast of Tunisia

\begin{tabular}{|c|c|c|c|c|c|}
\hline Waste & $\begin{array}{l}\text { Production } \\
\text { tons/year }\end{array}$ & $\begin{array}{l}\text { Potential } \\
\text { of biogas } 10^{6} \mathrm{~m}^{3}\end{array}$ & $\begin{array}{l}\text { Equivalent } \\
\text { in energy } \\
\text { GWh }\end{array}$ & Equivalent in Tep & Gain in USD/year \\
\hline Margins & 326,000 & 11.41 & 68.46 & 5891.57 & $12,322,800$ \\
\hline Livestock slaughterhouses & 7200 & 0.27 & 1.64 & 141.27 & 295,488 \\
\hline Poultry slaughterhouses & 15,360 & 2.76 & 16.59 & 1427.61 & $2,985,984$ \\
\hline Catering activities waste & 3586 & 0.22 & 1.29 & 111.10 & $232,372.8$ \\
\hline Liquid dropping & 224,000 & 15.68 & 94.08 & 8096.39 & $16,934,400$ \\
\hline Sludge waste water & 5342 & 1.34 & 8.01 & 689.59 & $1,442,340$ \\
\hline $\begin{array}{l}\text { Green waste from markets municipal and } \\
\text { wholesale }\end{array}$ & 4400 & 0.26 & 1.58 & 136.32 & 285,120 \\
\hline Fruit and vegetable canneries waste & 0 & 0.00 & 0.00 & 0.00 & 0 \\
\hline Winemaking waste & 700 & 0.11 & 0.67 & 57.83 & 120,960 \\
\hline Manure & 285,000 & 17.10 & 102.60 & 8829.60 & $18,468,000$ \\
\hline Total & 871,588 & 49.16 & 295 & $25,381.27$ & $53,087,464.8$ \\
\hline
\end{tabular}

\section{The potential of biogas in the Northeast of Tunisia}

Table 4 provides a synthesis of the total waste produced in the region of Northeast of Tunisia which is equal to 871,588 tons/year. Using this quantity, we can produce $49.1610^{6} \mathrm{~m}^{3}$ of biogas equivalent to $294.93 \mathrm{Gwh}$. This potential allows the gain more than 53,087,464.8 USD. This analysis can be used to assess the profitability threshold of the project.

\section{The potential of biogas in the Mideast of Tunisia}

The total quantity of waste produced in this zone is equal to 524,903 tons/year. Using this amount, we can produce $34.3310^{6} \mathrm{~m}^{3}$ of biogas equivalent to $206 \mathrm{Gwh}$. The shortfalls are estimated at $37,077,804$ USD. The main collected fractions are described in Table 5.

\section{The potential of biogas in the Midwest of Tunisia}

Table 6 presents a synthesis of the total waste produced in the region of Midwest of Tunisia which is equal to 443,593 tons/year. The treatment of this important quantity produces $32.7610^{6} \mathrm{~m}^{3}$ equivalent to $196.56 \mathrm{GWh}$. The shortfalls are estimated at 35,380,465.2 USD.

\section{The potential of biogas in South east of Tunisia}

The quantity of organic waste produced in this region is estimated at 390,765 tons/year. Using this quantity, we can produce $19.7510^{6} \mathrm{~m}^{3}$ /year equivalent to $118.48 \mathrm{Gwh}$. The shortfalls are estimated at 21,325,528.8 per year USD. The main collected fractions found are described in Table 7.

Table 5 Potential of biogas in the Mideast of Tunisia

\begin{tabular}{|c|c|c|c|c|c|}
\hline Waste & $\begin{array}{l}\text { Production } \\
\text { tons/year }\end{array}$ & $\begin{array}{l}\text { Potential } \\
\text { of biogas } 10^{6} \mathrm{~m}^{3}\end{array}$ & $\begin{array}{l}\text { Equivalent } \\
\text { in energy GWh }\end{array}$ & Equivalent in Tep & Gain in USD/year \\
\hline Margins & 0 & 0.00 & 0.00 & 0.00 & 0 \\
\hline Livestock slaughterhouses & 1900 & 0.07 & 0.43 & 37.28 & 77,976 \\
\hline Poultry slaughterhouses & 3960 & 0.71 & 4.28 & 368.06 & 769,824 \\
\hline Catering activities waste & 4015 & 0.24 & 1.45 & 124.39 & 260,172 \\
\hline Liquid dropping & 23,500 & 1.65 & 9.87 & 849.40 & $1,776,600$ \\
\hline Sludge waste water & 11,288 & 2.82 & 16.93 & 1457.14 & $3,047,760$ \\
\hline $\begin{array}{l}\text { Green waste from markets municipal and } \\
\text { wholesale }\end{array}$ & 1500 & 0.09 & 0.54 & 46.47 & 97,200 \\
\hline Fruit and vegetable canneries waste & 5500 & 0.33 & 1.98 & 170.40 & 356,400 \\
\hline Winemaking waste & 240 & 0.04 & 0.23 & 19.83 & 41,472 \\
\hline Manure & 473,000 & 28.38 & 170.28 & $14,654.04$ & $30,650,400$ \\
\hline Total & 524,903 & 34.33 & 205.99 & $17,727.01$ & $37,077,804$ \\
\hline
\end{tabular}


Table 6 Potential of biogas in the Midwest of Tunisia

\begin{tabular}{|c|c|c|c|c|c|}
\hline Waste & $\begin{array}{l}\text { Production } \\
\text { tons/year }\end{array}$ & $\begin{array}{l}\text { Potential } \\
\text { of biogas } 10^{6} \mathrm{~m}^{3}\end{array}$ & $\begin{array}{l}\text { Equivalent } \\
\text { in energy } \\
\text { GWh }\end{array}$ & Equivalent in Tep & Gain in USD/year \\
\hline Margins & 0 & 0.00 & 0.00 & 0.00 & 0 \\
\hline Livestock slaughterhouses & 1900 & 0.07 & 0.43 & 37.28 & 77,976 \\
\hline Poultry slaughterhouses & 0 & 0.00 & 0.00 & 0.00 & 0 \\
\hline Catering activities waste & 26,404 & 1.58 & 9.51 & 818.02 & $1,710,979.2$ \\
\hline Liquid dropping & 45,000 & 3.15 & 18.90 & 1626.51 & $3,402,000$ \\
\hline Sludge waste water & 30,189 & 7.55 & 45.28 & 3897.03 & $8,151,030$ \\
\hline $\begin{array}{l}\text { Green waste from markets municipal and } \\
\text { wholesale }\end{array}$ & 1300 & 0.08 & 0.47 & 40.28 & 84,240 \\
\hline Fruit and vegetable canneries waste & 3800 & 0.23 & 1.37 & 117.73 & 246,240 \\
\hline Winemaking waste & 0 & 0.00 & 0.00 & 0.00 & 0 \\
\hline Manure & 335,000 & 20.10 & 120.60 & $10,378.66$ & $21,708,000$ \\
\hline Total & 443,593 & 32.76 & 196.56 & $16,915.50$ & $35,380,465.2$ \\
\hline
\end{tabular}

Table 7 Potential of biogas in the Southeast of Tunisia

\begin{tabular}{|c|c|c|c|c|c|}
\hline Waste & $\begin{array}{l}\text { Production } \\
\text { tons/year }\end{array}$ & $\begin{array}{l}\text { Potential } \\
\text { of biogas } 10^{6} \mathrm{~m}^{3}\end{array}$ & $\begin{array}{l}\text { Equivalent } \\
\text { in energy } \\
\text { GWh }\end{array}$ & Equivalent in TOE & Gain in USD/year \\
\hline Margins & 189,000 & 6.62 & 39.69 & 3415.66 & $7,144,200$ \\
\hline Livestock slaughterhouses & 2800 & 0.11 & 0.64 & 54.94 & 114,912 \\
\hline Poultry slaughterhouses & 0 & 0.00 & 0.00 & 0.00 & 0 \\
\hline Catering activities waste & 12,441 & 0.75 & 4.48 & 385.44 & $806,176.8$ \\
\hline Liquid dropping & 17,000 & 1.19 & 7.14 & 614.46 & $1,285,200$ \\
\hline Sludge waste water & 4824 & 1.21 & 7.24 & 622.72 & $1,302,480$ \\
\hline $\begin{array}{l}\text { Green waste from markets municipal and } \\
\text { wholesale }\end{array}$ & 1700 & 0.10 & 0.61 & 52.67 & 110,160 \\
\hline Fruit and vegetable canneries waste & 0 & 0.00 & 0.00 & 0.00 & 0 \\
\hline Vinification waste & 0 & 0.00 & 0.00 & 0.00 & 0 \\
\hline Manure & 163,000 & 9.78 & 58.68 & 5049.91 & $10,562,400$ \\
\hline Total & 390,765 & 19.75 & 118.48 & $10,195.80$ & $21,325,528.8$ \\
\hline
\end{tabular}

\section{The potential of biogas in the South west of Tunisia}

Table 8 provides a synthesis of the total waste produced in this region of Tunisia which is equal to 13,241 tons/ year. The total quantity of biogas is estimated at 1 , $8710^{6} \mathrm{~m}^{3}$ equivalent to $11.23 \mathrm{Gwh}$. This potential allows the gain of more than 2,021,230.8 USD (Fig. 18).

\section{Discussion}

The study carried over a whole year in seven regions of Tunisia showed that the quantity of waste in Tunisia is enormous and constitutes an untapped potential to produce energy. Based on the samples collected from the seven regions, this work estimates that the untapped quantities of MSW can be a proficient venue to produce renewable energy forms to remedy energy deficiency and solve some of the major environmental impacts in the country.

This work suggests that the region's demographic, economic, and industrial status should be taken into consideration while implementing MSW treatment projects or in terms of generated compost or energy distribution. Because some Tunisian regions have stronger industries than the other regions, it would be better to take this into consideration while implementing MSW treatment projects. Moreover, some regions have stronger agricultural projects; therefore, some compost production sites should be implemented in the most agricultural concerned regions. This procedure 
Table 8 Potential of Biogas in the Southwest of Tunisia

\begin{tabular}{|c|c|c|c|c|c|}
\hline Waste & $\begin{array}{l}\text { Production } \\
\text { tons/year }\end{array}$ & $\begin{array}{l}\text { Potential } \\
\text { of biogas } 10^{6} \mathrm{~m}^{3}\end{array}$ & $\begin{array}{l}\text { Equivalent } \\
\text { in energy } \\
\text { GWh }\end{array}$ & Equivalent in TOE & Gain in USD/year \\
\hline Margins & 0 & 0.00 & 0.00 & 0.00 & 0 \\
\hline Livestock slaughterhouses & 1500 & 0.06 & 0.34 & 29.43 & 61,560 \\
\hline Poultry slaughterhouses & 0 & 0.00 & 0.00 & 0.00 & 0 \\
\hline Catering activities waste & 2246 & 0.13 & 0.81 & 69.58 & $14,5540.8$ \\
\hline Liquid dropping & 2800 & 0.20 & 1.18 & 101.20 & 211,680 \\
\hline Sludge waste water & 5695 & 1.42 & 8.54 & 735.15 & $1,537,650$ \\
\hline $\begin{array}{l}\text { Green waste from markets municipal and } \\
\text { wholesale }\end{array}$ & 1000 & 0.06 & 0.36 & 30.98 & 64,800 \\
\hline Fruit and vegetable canneries waste & 0 & 0.00 & 0.00 & 0.00 & 0 \\
\hline Vinification waste & 0 & 0.00 & 0.00 & 0.00 & 0 \\
\hline Manure & 0 & 0.00 & 0.00 & 0.00 & 0 \\
\hline Total & 13,241 & 1.87 & 11.23 & 966.36 & $2,021,230.8$ \\
\hline
\end{tabular}

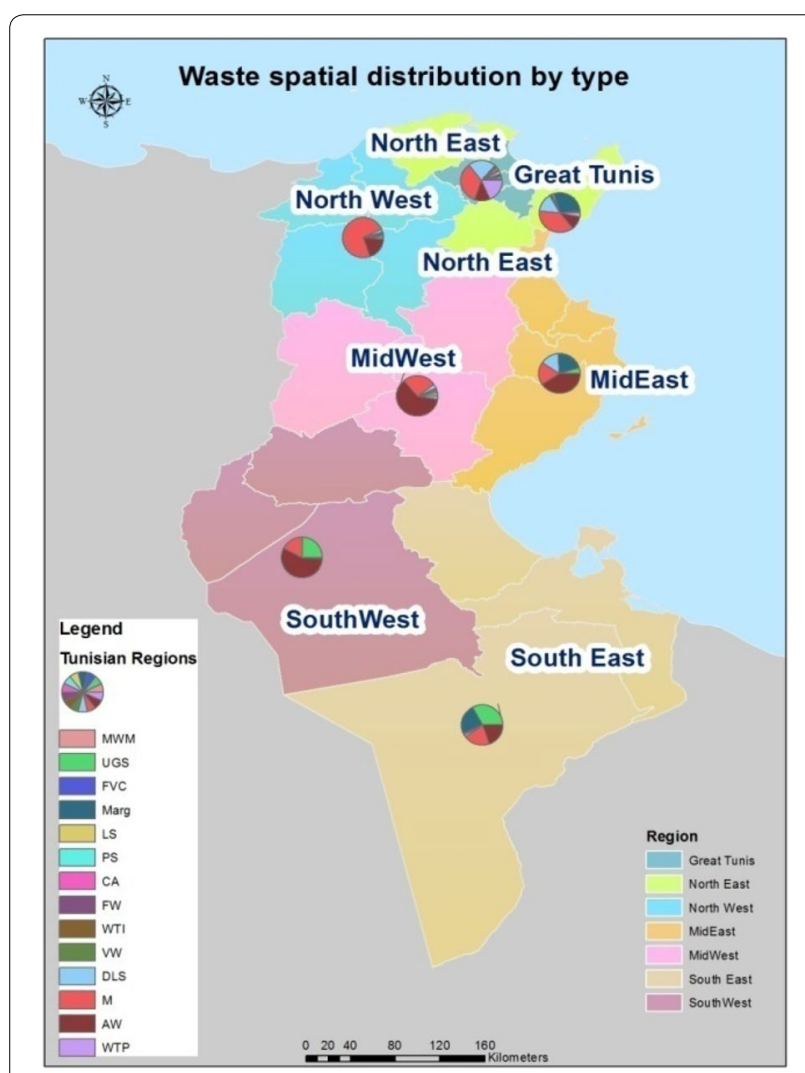

Fig. 18 Topology of valorizable organic waste in Tunisia can reduce transportation costs because of the proximity of production sites from the beneficiaries.

This work also suggests that treatment methods used to treat organic waste should be varied, either through anaerobic digestion (presence of significant quantities of organic waste) or by the use of other recent technologies. The incineration of wood products (also abundant in waste) can also produce electricity at low prices. It is recommended following this study to diversify the techniques of treatment and recovery of waste to exploit all the waste and preserve the environment.

\section{Conclusion}

The work presented in this paper lasted more than a year to identify and quantify the different types of waste produced in Tunisia. Samples of $200 \mathrm{~kg}$ were taken daily from four municipalities typical of Tunisian agglomerations. The sorting and characterization of different types of waste has shown that the quantities of waste are both enormous and very diversified and that it is possible to produce methane and electricity if recently suggested waste recovery technologies such as anerobic digester and fuel cells are used. It is also important to point out that it is possible to use new generations of bacteria for the processing of plastic waste. The use of termites is considered for the decompositions of waste from the wood industry and forest waste.

It is necessary to avoid the appearance of a rate of molds too important what can degrade the valorization of the waste thereafter.

We envisage the valorization of waste by methanisation using new control strategies of the bacteria responsible for methane production.

\section{Abbreviations}

MSW: municipal solid waste; EAB: electrochemically active bacteria; Km: kilometer; MFCs: microbiological fuels cells; COD: chemic oxygen demand: g: gramm; WWTPs: wastewater treatment plants; Gwh: Gigawatt hours; C/N: carbon-nitrogen ratio; VFAs: volatile fatty acids; OLR: organic loading rate, alkalinity; VS: volatile solids; HRT: hydraulic retention time. 


\section{Acknowledgements}

The authors would like to thank the National Agency for Waste Management in Tunisia for technical assistance and their help from time to time. The authors would like to thank Mrs. Fatma Fattoumi for the help in editing this work.

\section{Authors' contributions}

TW investigated references and developed the manuscript, figures and tables, $A B O$ investigated references and reviewed the manuscript, $M B$ investigated references and reviewed concept, topics and structure. All authors read and approved the final manuscript.

\section{Funding}

Not applicable.

\section{Availability of data and materials}

All data generated or analyzed during this study are included in this article.

\section{Ethics approval, consent to participate and consent for publication}

Authors have read and approved the manuscript to submit it to Bioresources and Bioprocessing.

\section{Competing interests}

The authors declare that they have no competing interests.

\section{Author details}

${ }^{1}$ Laboratory of Robotics, Informatics and Complex System, University of Tunis El Manar, Tunis, Tunisia. ${ }^{2}$ National School of Engineers of Carthage, University of Carthage, Carthage, Tunisia. ${ }^{3}$ Higher Institute of Information and Communication Technologies, University of Carthage, Carthage, Tunisia.

Received: 21 February 2019 Accepted: 29 September 2019 Published online: 14 October 2019

\section{References}

Abbasi SA, Gajalakshmi S (2015) Disposal of municipal solid waste with in situ termireactors: proof-of-concept. Bioresour Bioprocess 2(1):24. https://doi. org/10.1186/s40643-015-0050-Z

Akyürek Z (2018) Potential of biogas energy from animal waste in the Mediterranean Region of Turkey. J Energy Syst 2(4):160-167. https://doi. org/10.30521/jes.455325

Al-Addous M, Alnaief M, Class C, Nsair A, Kuchta K, Alkasrawi M (2017) Technical possibilities of biogas production from olive and date waste in Jordan. BioResources 12(4):9383-9395. https://doi.org/10.15376/biore s.12.4.9383-9395

Al-Addous M, Saidan MN, Bdour M, Alnaief M (2019) Evaluation of biogas production from the co-digestion of municipal food waste and wastewater sludge at refugee camps using an automated methane potential test system. Energies 12(1):32. https://doi.org/10.3390/en12010032

Andorrà I, Miró G, Espligares N, Mislata AM, Puxeu M, Ferrer-Gallego R (2019) Wild yeast and lactic acid bacteria of wine. Yeasts in biotechnology. Rijeka, IntechOpen. https://doi.org/10.5772/intechopen.84128

Ayodele TR, Ogunjuyigbe ASO, Alao MA (2017) Life cycle assessment of waste-to-energy ( $\mathrm{WtE}$ ) technologies for electricity generation using municipal solid waste in Nigeria. Appl Energy 201:200-218. https://doi. org/10.1016/j.apenergy.2017.05.097

Bertheau P, Cader C (2019) Electricity sector planning for the Philippine islands: considering centralized and decentralized supply options. Appl Energy 251:113393. https://doi.org/10.1016/j.apenergy.2019.113393

Bhat SA, Singh J, Vig AP (2017) Instrumental characterization of organic wastes for evaluation of vermicompost maturity. J Anal Sci Technol 8(1):2. https ://doi.org/10.1186/s40543-017-0112-2

Bouallagui H, Touhami Y, Cheikh RB, Hamdi M (2005) Bioreactor performance in anaerobic digestion of fruit and vegetable wastes. Process Biochem 40(3-4):989-995. https://doi.org/10.1016/j.procbio.2004.03.007

Bowan PA, Tierobaar MT (2014) Characteristics and management of solid waste in Ghanaian markets - a study of WA municipality. Civil Environ Res 6(1):114-119
Brunner PH, Rechberger H (2015) Waste to energy-key element for sustainable waste management. Waste Manag 37:3-12. https://doi.org/10.1016/j. wasman.2014.02.003

Chaturvedi V, Verma P (2015) Biodegradation of malachite green by a novel copper-tolerant Ochrobactrum pseudogrignonense strain GGUPV1 isolated from copper mine waste water. Bioresour Bioprocess 2(1):42. https://doi. org/10.1186/s40643-015-0070-8

Chaturvedi V, Verma P (2016) Microbial fuel cell: a green approach for the utilization of waste for the generation of bioelectricity. Bioresour Bioprocess 3(1):38. https://doi.org/10.1186/s40643-016-0116-6

Cherif H, Ayari F, Ouzari H, Marzorati M, Brusetti L, Jedidi N et al (2009) Effects of municipal solid waste compost, farmyard manure and chemical fertilizers on wheat growth, soil composition and soil bacterial characteristics under Tunisian arid climate. Eur J Soil Biol 45(2):138-145. https://doi. org/10.1016/j.ejsobi.2008.11.003

Chinnadurai S, Muruganantham B, Pradeep AK, Kinjal PP, Himanshu PB, Ganesh SP, Paulchamy C (2019) Evaluation of the biomethanation potential of enriched methanogenic cultures on gelatin. Bioresour Bioprocess 6(1):13. https://doi.org/10.1186/s40643-019-0247-7

Ciuta S, Antognoni S, Rada E, Ragazzi M, Badea A, Cioca L (2016) Respirometric index and biogas potential of different foods and agricultural discarded biomass. Sustainability 8(12):1311. https://doi.org/10.3390/su8121311

Deressa L, Libsu S, Chavan RB, Manaye D, Dabassa A (2015) Production of biogas from fruit and vegetable wastes mixed with different wastes. Environ Ecol Res 3(3):65-71. https://doi.org/10.13189/eer.2015.030303

Einarsson R, Persson UM (2017) Analyzing key constraints to biogas production from crop residues and manure in the EU—a spatially explicit model. PLOS ONE 12(1):e0171001. https://doi.org/10.1371/journal.pone.0171001

Eriksson M, Osowski CP, Malefors C, Björkman J, Eriksson E (2017) Quantification of food waste in public catering services - a case study from a Swedish municipality. Waste Manag 61:415-422. https://doi.org/10.1016/j. wasman.2017.01.035

Guerrero LA, Maas G, Hogland W (2013) Solid waste management challenges for cities in developing countries. Waste Manag 33(1):220-232. https:// doi.org/10.1016/j.wasman.2012.09.008

Gwenzi W, Chaukura N, Mukome FN, Machado S, Nyamasoka B (2015) Biochar production and applications in sub-Saharan Africa: opportunities, constraints, risks and uncertainties. J Environ Manag 150:250-261. https://doi. org/10.1016/j.jenvman.2014.11.027

Hirose A, Kasai T, Koga R, Suzuki Y, Kouzuma A, Watanabe K (2019) Understanding and engineering electrochemically active bacteria for sustainable biotechnology. Bioresour Bioprocess 6(1):10. https://doi.org/10.1186/ s40643-019-0245-9

Hoo PY, Patrizio P, Leduc S, Hashim H, Kraxner F, Tan ST, Ho WS (2017) Optimal biomethane injection into natural gas grid-biogas from palm oil mill effluent (POME) in Malaysia. Energy Procedia 105:562-569. https://doi. org/10.1016/j.egypro.2017.03.357

Igliński B, Buczkowski R, Cichosz M (2015) Biogas production in Polandcurrent state, potential and perspectives. Renew Sustain Energy Rev 50:686-695. https://doi.org/10.1016/j.rser.2015.05.013

Karaca C, Öztürk HH (2017) Biogas production potential from animal manure in Osmaniye province. In: Proceeding book of international advanced researches and engineering congress, pp 2302-2306

Kaza S, Yao L, Bhada-Tata P, Van Woerden F (2018) What a waste 2.0: a global snapshot of solid waste management to 2050. World Bank Publications. https://openknowledge.worldbank.org/handle/10986/2174

Khandelwal H, Dhar H, Thalla AK, Kumar S (2018) Application of life cycle assessment in municipal solid waste management: a worldwide critical review. J Clean Prod. https://doi.org/10.1016/j.jclepro.2018.10.233

Kigozi R, Aboyade A, Muzenda E (2013) Biogas production using the organic fraction of municipal solid waste as feedstock. Int J Res Chem Metall Civil Eng 1(1):107-114. https://doi.org/10.15242/IJRCMCE.E1113563

Kumar K, Yadav AN, Kumar V, Vyas P, Dhaliwal HS (2017) Food waste: a potential bioresource for extraction of nutraceuticals and bioactive compounds. Bioresour Bioprocess 4(1):18. https://doi.org/10.1186/s40643-017-0148-6

Majeed A, Batool S, Chaudhry M (2018) Environmental quantification of the existing waste management system in a developing world municipality using EaseTech: the case of Bahawalpur, Pakistan. Sustainability 10(7):2424. https://doi.org/10.3390/su10072424

Makisha N, Semenova D (2018) Production of biogas at wastewater treatment plants and its further application. In: MATEC web of conferences, vol 144, 
p 04016. EDP Sciences. https://doi.org/10.1051/matecconf/2018144040 16

Miezah K, Obiri-Danso K, Kádár Z, Fei-Baffoe B, Mensah MY (2015) Municipal solid waste characterization and quantification as a measure towards effective waste management in Ghana. Waste Manag 46:15-27. https:// doi.org/10.1016/j.wasman.2015.09.009

Mihai FC, Ingrao C (2018) Assessment of biowaste losses through unsound waste management practices in rural areas and the role of home composting. J Clean Prod 172:1631-1638. https://doi.org/10.1016/j.jclep ro. 2016.10 .163

Minghua Z, Xiumin F, Rovetta A, Qichang H, Vicentini F, Bingkai L et al (2009) Municipal solid waste management in Pudong New Area, China. Waste Manag 29(3):1227-1233. https://doi.org/10.1016/j.wasman.2008.07.016

Noya I, Inglezakis V, González-García S, Katsou E, Feijoo G, Moreira MT (2018) Comparative environmental assessment of alternative waste management strategies in developing regions: a case study in Kazakhstan. Waste Manag Res 36(8):689-697. https://doi.org/10.1177/0734242X18786388

Oguntoke O, Amaefuna BA, Nwosisi MC, Oyedepo SA, Oyatogun MO (2019) Quantification of biodegradable household solid waste for biogas production and the challenges of waste sorting in Abeokuta Metropolis, Nigeria. Int J Energy Water Resour 3(3):253-261. https://doi.org/10.1007/ s42108-019-00033-9

Ogur EO, Mbatia S (2013) Conversion of kitchen waste into biogas. Int J Eng Sci 11(2):70-76

Ojikutu Abimbola O, Osokoya Olumide O (2014) Evaluation of biogas production from food waste. Int J Eng Sci 3(1):1-7

Oyiwona GE, Ogbonna JC, Anyanwu CU, Okabe S (2018) Electricity generation potential of poultry droppings wastewater in microbial fuel cell using rice husk charcoal electrodes. Bioresour Bioprocess 5(1):13. https://doi. org/10.1186/s40643-018-0201-0

Panepinto D, Zanetti MC (2018) Municipal solid waste incineration plant: a multi-step approach to the evaluation of an energy-recovery configuration. Waste Manag 73:332-341. https://doi.org/10.1016/j.wasma n.2017.07.036

Paritosh K, Kushwaha SK, Yadav M, Pareek N, Chawade A, Vivekanand V (2017) Food waste to energy: an overview of sustainable approaches for food waste management and nutrient recycling. Biomed Res Int. https://doi. org/10.1155/2017/2370927

Recebli Z, Selimli S, Ozkaymak M, Gonc O (2015) Biogas production from animal manure. J Eng Sci Technol 10(6):722-729

Report on the Solid Waste Management in TUNISIA (2014) Deutsche Gesellschaft für Internationale Zusammenarbeit (GIZ). https://www.retec h-germany.net/fileadmin/retech/05_mediathek/laenderinformationen/ Tunesien_laenderprofile_sweep_net.pdf

Saladié Ò (2016) Determinants of waste generation per capita in Catalonia (North-eastern Spain): the role of seasonal population. Eur J Sustain Dev 5(3):489-504. https://doi.org/10.14207/ejsd.2016.v5n3p489

Santoro C, Arbizzani C, Erable B, leropoulos I (2017) Microbial fuel cells: from fundamentals to applications. A review. J Power Sour 356:225-244. https ://doi.org/10.1016/j.jpowsour.2017.03.109

Sarkar P, Chourasia R (2017) Bioconversion of organic solid wastes into biofortified compost using a microbial consortium. Int J Recycl Org Waste Agric 6(4):321-334. https://doi.org/10.1007/s40093-017-0180-8

Scarlat N, Dallemand JF, Monforti-Ferrario F, Nita V (2015) The role of biomass and bioenergy in a future bioeconomy: policies and facts. Environ Dev 15:3-34. https://doi.org/10.1016/j.envdev.2015.03.006

Sindibu T, Solomon SS, Ermias D (2018) Biogas and bio-fertilizer production potential of abattoir waste as means of sustainable waste management option in Hawassa City, southern Ethiopia. J Appl Sci Environ Manag 22(4):553-559. https://doi.org/10.4314/jasem.v22i4.21

Singh B, Ryan J (2015) Managing fertilizers to enhance soil health. International Fertilizer Industry Association, Paris, France, pp 1-24. http://www.fertilizer .org/

Tatàno F, Caramiello C, Paolini T, Tripolone L (2017) Generation and collection of restaurant waste: characterization and evaluation at a case study in Italy. Waste Manag 61:423-442. https://doi.org/10.1016/j.wasma n.2017.01.020

Trang PTT, Dong HQ, Toan DQ, Hanh NTX, Thu NT (2017) The effects of socioeconomic factors on household solid waste generation and composition: a case study in Thu Dau Mot, Vietnam. Energy Procedia 107:253-258. https://doi.org/10.1016/j.egypro.2016.12.144

Varadharajan S, Subramaniyan V (2014) Production of biosurfactant by Pseudomonas aeruginosa PB3A using agroindustrial wastes as a carbon source. Malays J Microbiol 10(1):57-62. https://doi.org/10.21161/ mjm.56813

Yesuenyeagbe Fiagbe AK (2017) Sustainable treatment of municipal solid waste with plasma gasification as an option in Ghana. World J Eng Res Technol 3(5):449-459

\section{Publisher's Note}

Springer Nature remains neutral with regard to jurisdictional claims in published maps and institutional affiliations.

\section{Submit your manuscript to a SpringerOpen ${ }^{\circ}$ journal and benefit from:}

- Convenient online submission

- Rigorous peer review

- Open access: articles freely available online

- High visibility within the field

- Retaining the copyright to your article

Submit your next manuscript at $\boldsymbol{\nabla}$ springeropen.com 